\title{
エアレーションによるD0増加過程に 気泡径および水質が及ぼす影響の研究 INFLUENCE OF BUBBLE DIAMETER AND WATER QUALITY ON DISSOLVED OXYGEN TRANSFER DUE TO AERATION
}

\author{
木俣陽一 1 京藤敏達 2 ・歌川紀之 ${ }^{3}$ \\ Yoichi KIMATA, Harumichi KYOTOH and Noriyuki UTAGAWA \\ 1正会員 若築建設株式会社（广153-0064 東京都目黒区下目黒2-23-18） \\ 2正会員 工博 筑波大学助教授 システム情報工学研究科（テ305-873 茨城県つくば市天王台1-1-1） \\ 3正会員 工博＼cjkstart佐藤工業株式会社（テ243-0123 神奈川県厚木市森の里青山14-10）
}

\begin{abstract}
At the aqua-area with water pollution, the improvement of the water environment has been attempted by increasing the dissolved oxygen (DO) in terms of various ventilations. In the present study, an efficient method for aeration was investigated through the aeration experiments carried out in tap water, pond water and salt water, where the DO, the $\mathrm{pH}$, and the redox potential were measured and examined. The DO-increase experiments for pond water showed that the efficiency of aeration strongly depends on the water quality. As the ventilation increases, the $\mathrm{pH}$ increases in the air-stone and the singe micro-bubble generator for tap and pond water, but in the series micro-bubble generator it increases initially and decreases later. The ORP of tap water increases initially and decreases later, and that of pondwater decreases strongly. Moreover, an increase of the dissolved oxygen of pure water by aeration is evaluated it by the numerical analysis.
\end{abstract}

Key Words : aeration, micro-bubbles, bubble diameter, dissolved oxygen, Henry's law, water quality, aerators structure

\section{1.はじめに}

水質が污濁した水域では, 人間活動に起因した流入負 荷が水域の持つ自浄能力を超え, 底層付近では溶存酸素

（以下，D0）が消費され貧酸素状態を呈している．この ような水域は, 流入負荷が軽減されても自浄能力のポテ ンシャルが低下しており，水質の回復には多くの時間を 要する. 効率的な水質浄化には, 低下した自浄能力を回 復させることが重要であり, ひとつの手法として曝気に よるD0の増加が図られている，曝気によるD0の上昇を図 る上で考慮すべき要因は, 水深, 躍層および水質であり, 効率的な曝気にはこれらの状況を把握した適切な気体の 選定, 気泡径や気体流量の設定が必要である。また，微 小気泡による水域環境改善の効果が注目され，泡沫浮上 分離, D0の上昇, 洗浄効果や生物活性の向上に対し多く の研究がなされてきた ${ }^{1,2)}$. しかし，D0の上昇について は, 気泡径がD0上昇に及ぼす効果を定量的に検証した研 究例は少ないのが現状である.

本研究は, 曝気をおこなう上で必要となる水域に応じ た空気量や気泡径を設定するための基礎資料の取得を目
的に，水質が異なる水を用いた水槽試験により $0_{2}$ 供給量 に対するDO増加量および水質変化を調查した．また，D0 の増加が気泡径をパラメータとした数值解析により, 評 価可能であるか，実験シミュレーションを実施すること により検証した.

\section{2. 曝気試験方法}

\section{（1）水質によるD0の増加 (CASE-A, B)}

\section{a）試験装置}

試験は，図-1に示すアクリル製円筒水槽（ $\phi 23 \mathrm{~cm} \times$ H50cm）を用い，試験水を水深 $40 \mathrm{~cm}$ （水量：16.6L）まで 注水して行った．水中への給気は，循環水の放出口に縮 流部，直管部およぶ急拡部からなる図-2に示す直径 $13 \mathrm{~mm}$ の旋回流式マイクロバブル発生装置（以下，MB発生装 置）光）用いて $10 \mathrm{~mL} / \mathrm{min}$ 純酸素（酸素ボンべ）を微細 気泡として供給した．なお，純酸素は，循環水管路の途 中から注入し, 陸上ポンプ (Ebara Pump 揚程 $5.2 \mathrm{~m}$, 100V，180W）で試験水を6L/minで循環させた. 


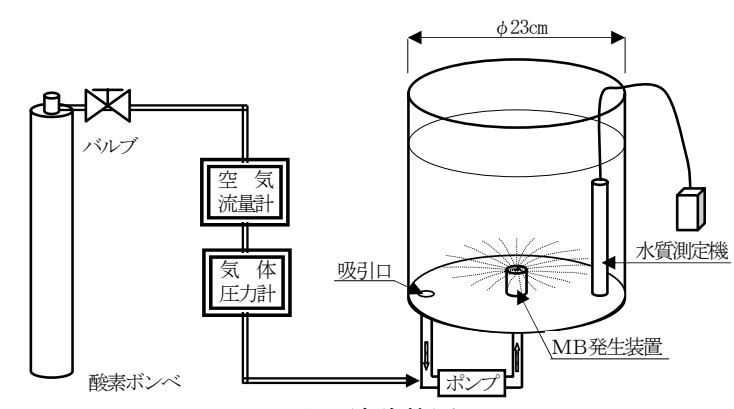

図-1 試験装置

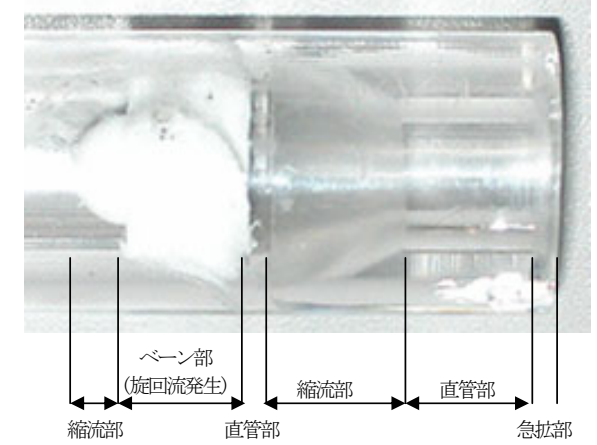

図-2＼cjkstart旋回流式マイクロバブル発生装置

表-1 試験水

\begin{tabular}{|c|c|c|}
\hline CASE & 水質 & 備考 \\
\hline A1 & 水道水 & 試験直前に採取 \\
\hline A2 & 純水 & 共栄製薬 (株) 製 \\
\hline A3 & 蒸留水 & 和光純薬工業 (株) 製 \\
\hline $\mathrm{A} 4$ & 池水 & 筑波大内の池より採取 \\
\hline B1 & 水道水 & 試験直前に採取 \\
\hline $\mathrm{B} 2-1$ & \multirow{3}{*}{ 池水 } & 筑波大学内の池より採取 \\
\hline $\mathrm{B} 2-2$ & & 霞ヶ浦（掛馬沖）より採取 \\
\hline $\mathrm{B} 2-3$ & & 霞ヶ浦（土浦沖）より採取 \\
\hline B3-1 & \multirow{2}{*}{ 食塩水 } & 水道水に食塩を1\%添加 \\
\hline B3-2 & & 水道水に食塩を $2 \%$ 添加 \\
\hline
\end{tabular}

\section{b）試験水}

水中での気体の溶解速度は, 気体の表面積, 水との接 触時間，水の温度および塩分濃度などが影響することが 知られている. このため, 池水などの浮遊物質を含む水 は, 気体の表面に浮遊物質が付着し有効表面積を減少さ せ，気泡の溶解速度を低下させる，言い換えれば，不純 物が含まれない清澄な水は, 気泡の溶解速度が速く, 気 体の溶解量の増加が容易であるといえる.

試験は水質が気体の溶解速度に与える影響の把握を目 的に, CASE-Aでは清澄水の水質, CASE-Bでは含有物質の 濃度に観点を置き，表-1に示寸試験水を用いた。

\section{c）水質測定}

水質の変化は，水槽内に投げ込み式のセンサープロー ブを設置し, 水温, $\mathrm{D} 0, \mathrm{pH}$, 酸化還元電位（以下, ORP）を連続的に測定した。 なお，酸素の供給は，測定 機の性能よりDOが $20 \mathrm{mg} / \mathrm{Lまでとした．また，センサープ}$ ローブは気泡の付着を抑止するために間欠的に水槽内で 振動を加えた.

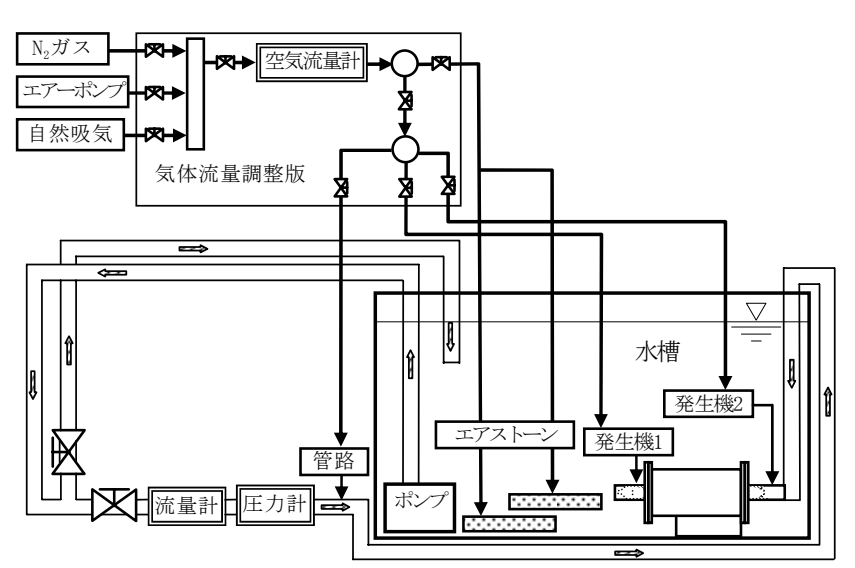

図-3 試験装置

表-2 試験パラメータ

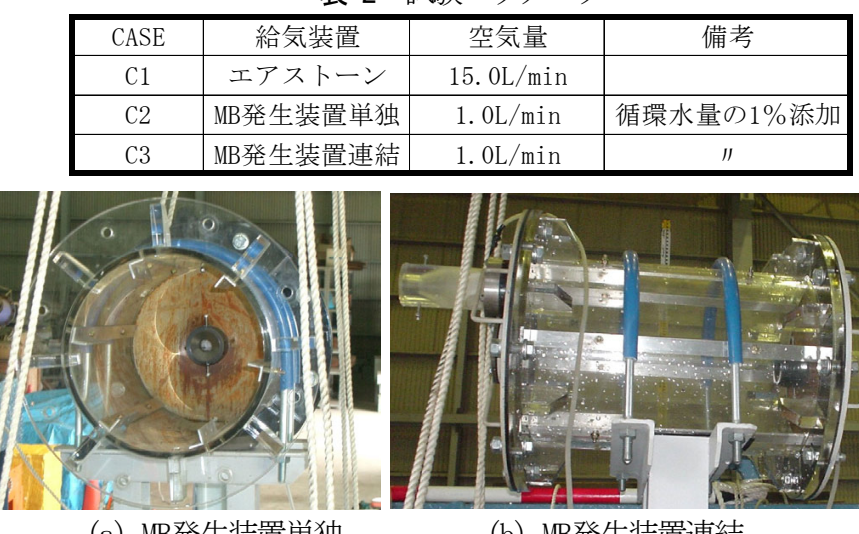

（a）MB発生装置単独

図-4 発生装置

（b）MB発生装置連結

（2）気泡径によるDO増加量の確認（CASE-C）

\section{a）試験装置}

試験は，図-3に示寸鋼製角形水槽（L3. $3 \mathrm{~m} \times$ B1. $7 \mathrm{~m} \times$ H1. $8 \mathrm{~m}$ ）に水道水を水深 $1.6 \mathrm{~m}$ （水量: $9.0 \mathrm{~m}^{3}$ ) まで注 水して行った. 給気装置は, エアストーン（セラミック 製, 気孔径: 平均 $15 \mu \mathrm{m}$ ) と実機を想定し 2 章(1)節で使 用したMB発生装置（図-2参照）を $\phi 5.0 \mathrm{~cm}$ に型化した ものを用いた．給気装置の設置水深は，エアストーンは 水深1. $6 \mathrm{~m}$ に, MB発生装置は給気位置の中心部が水深1. 1 mの位置とした. MB発生装置による給気は, 高揚程水中 ポンプ（鶴見ポンプ：KTV-37H 口径2インチ，全揚程 30 m）を接続した管路の途中に空気を注入し，MB発生措置 により微小気泡を発生させた. なお, 本ポンプにより水 槽内で, $100 \mathrm{~L} / \mathrm{min}$ 水が循環する.

\section{b）試験パラメータ}

給気装置により発生した気泡の径（表面積）が，DOの 増加に影響を与えるため, 発生する気泡径が異なると考 えた3種類の発生装置（図-4参照）を用いた。なお，MB 発生装置では, 給気量が流量の $0.5 \%$ で半径 $50 \mu \mathrm{m}, 1 \%$ で100 $\mu \mathrm{m}$ の気泡が多く生成されることが確認されている. 給気装置毎の空気添加量は, 表-2に示寸量に設定した.

c) 試験方法

発生機の効率は, 水中に曝気した空気によるD0の上昇 

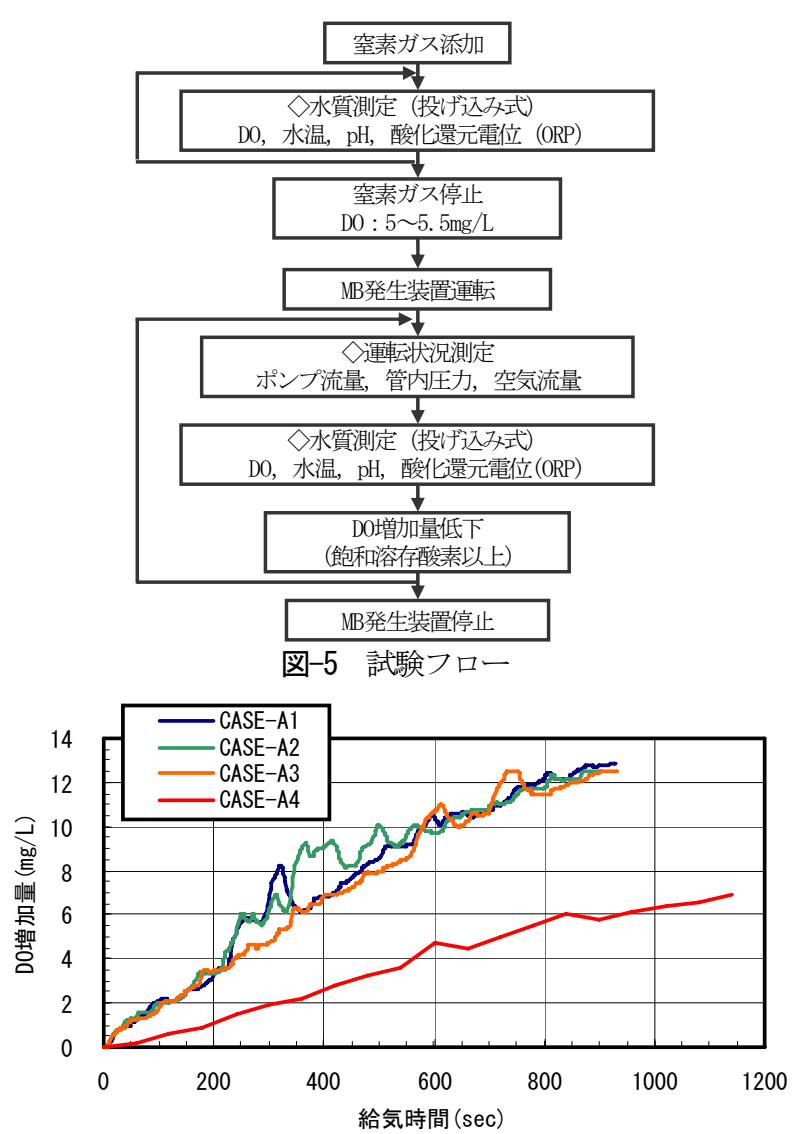

図-6 給気時間とDO増加量 (CASE-A : 清澄水)

量で判定した．試験は図-5に示すフローで実施した。 な お，3種類の発生装置による水質の変化の測定は，空気 の供給前に水槽内に窒素ガスをエアストーンから供給し， D0を $5 〜 5.5 \mathrm{mg} / \mathrm{L}$ まで低下させた状態から開始した．水質 の測定は，水槽内に投げ込み式のセンサープローブを水 深0. $8 \mathrm{~m}$ の位置に設置し，水温， DO, pH，ORPを連続的に 測定した。 なお，気泡の付着は，間欠的にセンサープ ローブへ振動を加えたことで抑止した.

\section{3. 曝気試験結果}

\section{（1）清澄水の質の違いによるD0の増加（CASE-A）}

清澄水（水道水, 純水および蒸留水) に一定量で酸素 を供給した時の給気時間とD0増加量の関係を図-6に示す。 D0の増加量で比較したのは, 試験毎の初期D0が異なった ためである. 池水は清澄水との比較のために用いた.

DOは，いずれの水も給気時間に対して直線的な増加を 示し，三つの清澄水はほぼ同じD0増加勾配となったが， 池水のD0増加勾配は清澄水の約半分であった．また，気 泡発生時の水槽内は，清澄水はわずかに白濁した程度で あったが，池水は背面が透視できないほどであった．こ れは, 今回の気泡径では, 池水では気泡に不純物が付着 し，気泡が残留し溶解速度が低下したことを示している。 給気時間と水質 $(\mathrm{pH}, \mathrm{ORP})$ の変化を図-7に示寸。 $\mathrm{pH}$
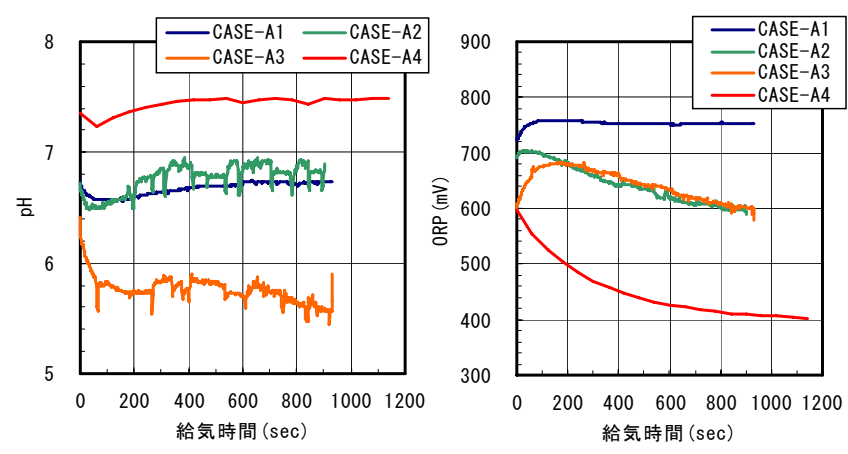

図-7 給気時間と水質変化 (CASE-A : 清澄水)

表-3 池水の性状

\begin{tabular}{|c|c|c|c|c|}
\hline CASE & 濁度 & $\mathrm{pH}$ & ORP $(\mathrm{mV})$ & 備考 \\
\hline $\mathrm{B} 2-1$ & 2.7 & 9.83 & 510 & 学内池採取 \\
\hline $\mathrm{B} 2-2$ & 23.5 & 7.79 & 459 & 霞ヶ浦採取 \\
\hline $\mathrm{B} 2-3$ & 15.7 & 7.69 & 439 & " \\
\hline
\end{tabular}

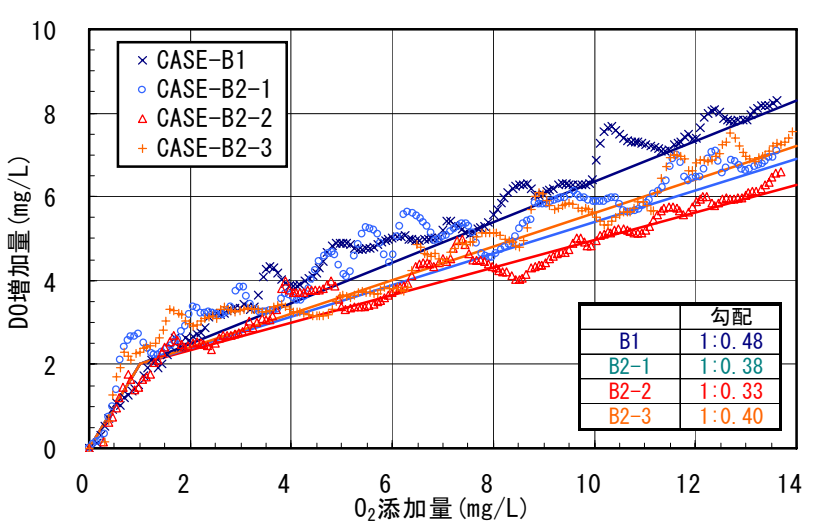

図-8 $\mathrm{O}_{2}$ 添加量とDO増加量 (CASE-B2 : 湖沼水)

は給気量の増加に伴い, 蒸留水を除く 3 種類は増加, 蒸 留水は低下した. これは, 蒸留水の場合, 水面から溶け 込む $\mathrm{CO}_{2}$ の影響でpHが低下し，他の三種類の水では試験 開始時に溶存した $\mathrm{CO}_{2}$ が酸素の増加により大気中に排出 され $\mathrm{pH}$ 渵加したと考える，ORPは，水道水，純水と蒸 留水, 池水で異なる傾向を示した。 これは, MB発生装置 で負電荷に帯電した気泡の供給と水中の不純物の影響で, 水道水は残留塩素による増加, 他は水中の微細気泡の増 加で低下したと考える. なお, 蒸留水の初期0RPの増加 はpHの低下と同調しており， $\mathrm{CO}_{2}$ の増加が原因と言える.

\section{（2）不純物質のD0の増加への影響（CASE-B2） \\ a) 湖沼水}

試験に用いた湖沼水の性状を表-3に示す．なお，池水 は強いアンモニア臭がし, pHが高かった.

湖沼水の0 $0_{2}$ 添加量とD0増加量の関係を図-8に示寸．湖 沼水のD0の増加は, 不純物の影響で水道水に比べ69〜 83\%と低いものであった． 不純物の中で濁り（濁度）に 着目すると霞ヶ浦の水（B2-2，B2-3） は，図-8に示すよ うに濁りの多いB2-2の方がD0の増加勾配が小さいもので あった．これは，気泡に濁り物質が付着することで溶解 速度が低下したためと考える. また, 水質が異なるB $2-1$ とB2-3では濁りの多いB2-3の増加勾配が大きく, D0増加 

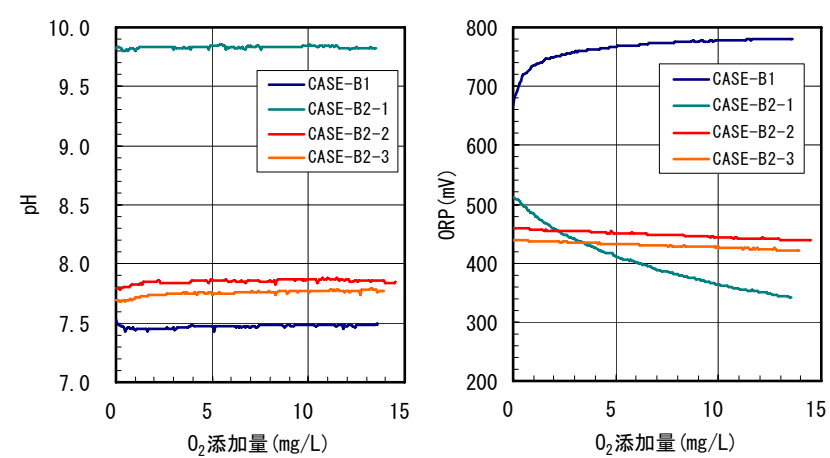

図-9 O $_{2}$ 添加量と水質変化 (CASE-B2 : 湖沼水)

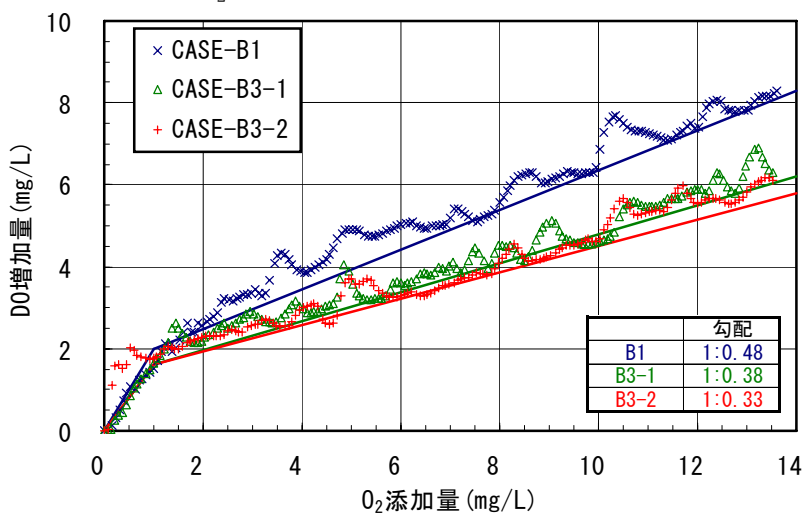

図-10 $0_{2}$ 添加量とD0増加量 (CASE-B3 : 食塩水)
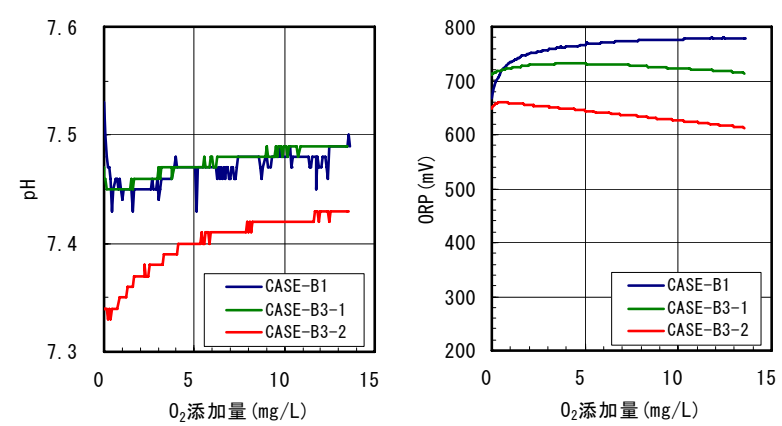

図-11 $0_{2}$ 添加量と水質変化 (CASE-B3 : 食塩水)

には濁り以外の不純物の影響も大きいと言える.

$\mathrm{O}_{2}$ 添加量による水質 $(\mathrm{pH}, \mathrm{ORP})$ の変化を図-9に示寸 $\mathrm{pH}$ H $0_{2}$ 添加によるDOおよび带電した微小気泡の増加で微 増, $\mathrm{ORP} は \mathrm{O}_{2}$ 添加の増加に伴い低下した。 また, 初期 $\mathrm{pH}$ が高い池水は $150 \mathrm{mV}$ 以上の低下を示した。これは，試験 終了後にアンモニア臭が低下したことより，アンモニア が水中より析出され，ORPが低下したと考える.

\section{b）食塩水}

$\mathrm{O}_{2}$ 添加量とD0増加量の関係を図-10に示す．食塩水の D0の増加は水道水に比べ低く, 塩分濃度の増加により増 加勾配は低下した．試験に用いた食塩水は，水道水に食 塩を加え1日間放置したもので不純物の含有量は少なく D0の増加勾配の低下は塩分濃度の増加が影響したと言え る. 今回の試験は水道水に食塩を溶かした不純物の少な い水を使用したが，海域の海水は塩分濃度が試験水より 更に高いこと，かつ多くの不純物を含むことより，海域 でのD0の増加勾配は更に小さくなることが予想される.

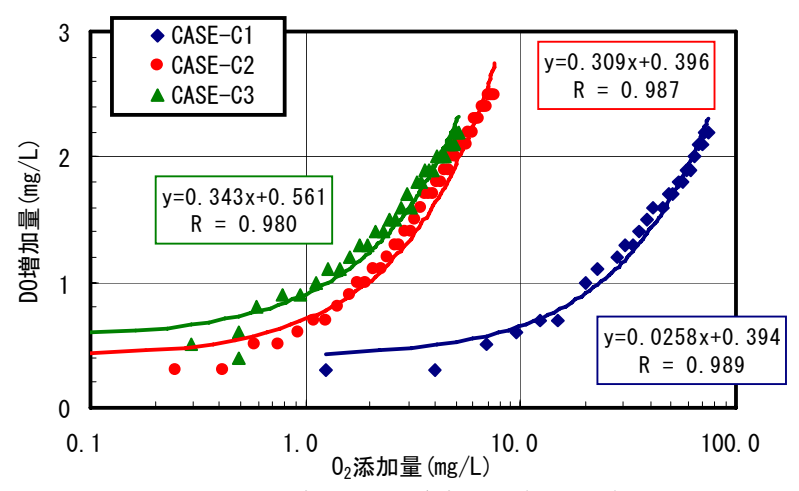

図-12 $\mathrm{O}_{2}$ 添加量とD0増加量 $(\mathrm{CASE}-\mathrm{C})$
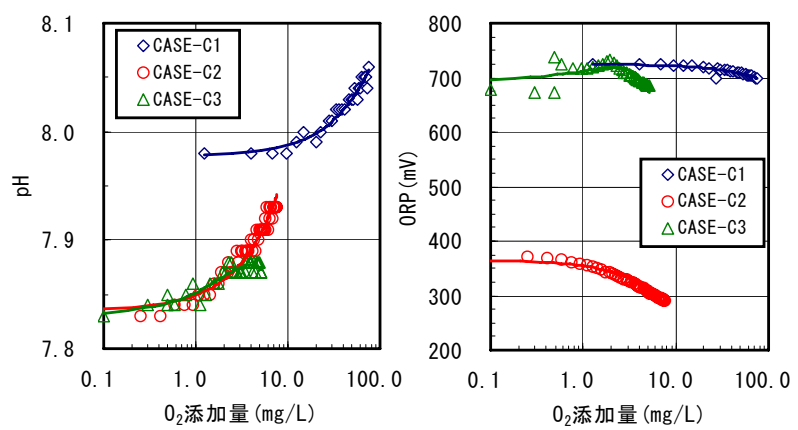

図-13 $0_{2}$ 添加量と水質変化 $(\mathrm{CASE}-\mathrm{C})$

水質 $(\mathrm{pH}, \mathrm{ORP})$ の変化を図-11に示す。 $\mathrm{pH}$ は，いずれ も $0_{2}$ 添加量の増加に伴いDOおよび帯電した微小気泡の増 加により微増した． ORPは， $\mathrm{O}_{2}$ 添加量の増加に伴い一旦 上昇した後に低下した. 食塩水（水道水で製作後に1日 間放置) は，採取直後の水道水に比べ残留塩素が少なく （ORPの増加量が小さい）， $\mathrm{O}_{2}$ 添加量に伴い増加した負 電荷に帯電した微小気泡により低下したと考える。また, 塩分濃度が高い $2 \%$ 食塩水では， $1 \%$ 食塩水に比べORPの低 下が約40mV多いのは, D0の増加が小さくかつ, 微小気泡 による白濁が多かったことから，負電荷に帯電した微小 気泡の濃度がより高くなったためと言える。

\section{（3）気泡径によるDO増加量（CASE-C）}

水道水を用いたMB発生装置による $0_{2}$ 添加量とDO増加量 の関係を図-12に示寸．なお，試験では空気を用いたが， 空気中の $0_{2}$ 分圧から $0_{2}$ 添加量を算出し示した.

CASE-C2のMB発生装置単独（以下，MB単独）の場合は, エアストーンより細かな微細気泡を供給することで約 12 倍のDO増加効果を発揮した. MB 発生装置連結（以下，MB 連結）は，最初のMB発生装置で発生した気泡が更にせん 断の場を通過することでより細泡化し，MB単独の1.1倍 に酸素の溶解速度を向上させた。 しかし, MB発生装置で 飽和DO值を超えた水は，曝気を停止すると直ぐに飽和DO 值以下に低下寸る傾向を示した。これは，溶解速度が遅 い窒素の溶解で，水中での窒素の分圧が高くなったため と考える.

また，実験条件や着目したDOのレンジが異なるが，気 体の種類に着目寸ると, MB単独のD0の増加勾配は純酸素 (CASE-B1) では0.48，空気（CASE-C2）では0.31であっ 
た. 空気の給気で純酸素と同じ量のD0を増加させるには, 空気中の酸素の分圧を考慮すると7.4倍の空気量の供給 が必要であり, 空気中の窒素の存在がD0の増加を抑制さ せていると思われる. このことより, 純酸素を用いるこ とはD0の速やかな増加や給気装置の小型化に優位である. $\mathrm{O}_{2}$ 添加量による水質 $(\mathrm{pH}, \mathrm{ORP})$ の変化を図-13に示す. なお，MB単独のORPの初期值が小さいのは，2日間静置し た水道水を用いたため残留塩素の低下が原因である. $0_{2}$ の供給量の増加に伴う $\mathrm{pH}$ の変化は, $\mathrm{CASE}-\mathrm{C} 2$ とC3を比較 すると，CASE-C2は上昇，CASE-C3は一旦上昇後に低下し た. $\mathrm{O}_{2}$ の供給量の増加に伴うORPは，CASE-C2は低下（残 留塩素が低い），CASE-C3は一旦上昇後低下した。また， 供給気体が異なるがCASE-B1のORPは，供給量の増加に伴 い増加した。

これらの結果より, MB連結（CASE-C3）では最初のMB 発生装置で発生した微小気泡を再度せん断の場に供給し, 気泡の微細化と帯電量の増加という効果を発揮したと考 えられる.

\section{4. 気体の溶解を支配する条件}

水域におけるD0の上昇には，水深，波や流れ，密度成 層などの物理的要因や水質などの生物化学的要因を事前 に把握し，それに合った曝気条件，例えば，気体の流量 や気泡径，気体の種類を選定する必要がある.

本章では，気体の溶解の理論式を用い，気体の溶解に 影響する因子を整理するとともに，その結果を用いて， 前章で実施した実験の溶存酸素上昇を予測する.

\section{（1）気体の溶解の基礎方程式}

気泡内気体の溶出速度はヘンリーの法則にしたがって 次式で算定される ${ }^{4)}$.

$$
\frac{d M_{j}}{d t}=\frac{4 \pi R^{2} K_{L}}{H_{j}}\left(P_{j}-p_{j}\right)
$$

ここで， $M_{j}$ は気泡内の気体のモル数, $K_{L}$ は気体溶解速 度, $R$ は気泡半径, $H_{j}$ はHenry定数である. また, 下付き 添字 $j$ はOもしくはNであり，それぞれ酸素および窒素 を表わす。 $p_{j}$ および $P_{j}$ はそれぞれ気泡内と液体内におけ る気体の分圧である.

気体溶解速度 $K_{L}$ は, (1) 清澄水などの場合は $K_{L}=D_{j} S_{j} / 2 R$, (2)污れた水の場合は $K_{L}=\alpha R: R \leq R_{c}$,

$K_{L}=\alpha R_{c}: R \geq R_{c}$ となる. ここで， $D_{j}$ は気体の液体内に おける拡散係数, $S_{j}$ はSherwood数, $\alpha, R_{c}$ は実験定数であ る.

清澄水の場合, Sherwood数は気泡周りの液体の流速場 から決定され ${ }^{5)}$,

$$
\begin{aligned}
& S_{j}=1+\left(1+R_{e} S_{c j}\right)^{1 / 3} \quad ; \quad R_{e}<1 \\
& S_{j}=1+\left(S_{c j}+\frac{1}{R_{e}}\right)^{1 / 3} R_{e}^{0.41} ; 1<R_{e}<400
\end{aligned}
$$

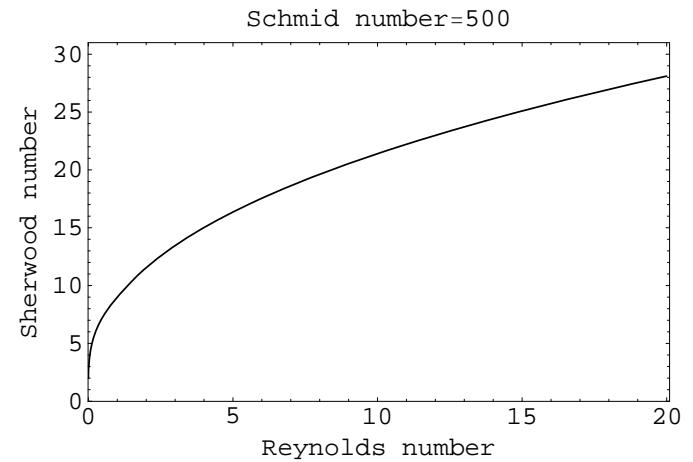

図-14 Sherwood数のReynolds数依存性

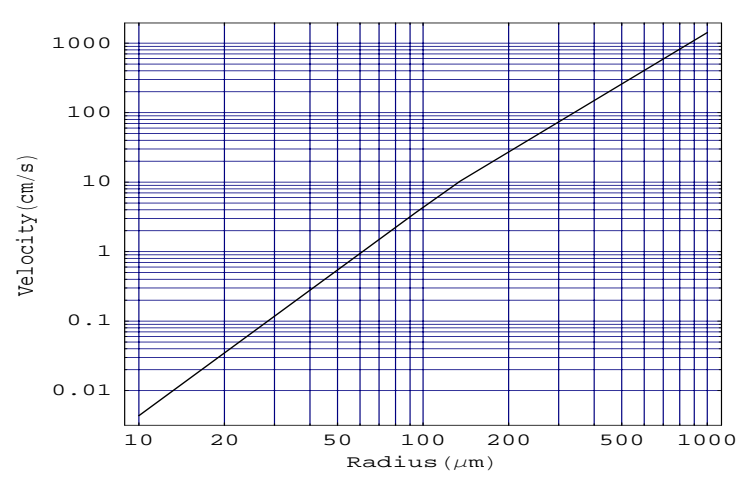

図-15 気泡半径と浮上速度の関係 $\left(\mathrm{R}_{\mathrm{b}}=100 \mu \mathrm{m}\right)$

となる. ここで, $R_{e}$ はReynolds数 $\left(R_{e}=2 R U / v\right), S_{C j}$ はSchmid数 $\left(S_{C j}=v / D_{j}\right), U$ は気泡の上昇速度であり次 式で与えられる゙).

$$
\begin{aligned}
& \text { 固体球: } U=(2 R)^{2} \frac{\rho_{\ell} g}{18 \mu} \quad \text { for } \quad R<R_{b} \\
& \text { 流体球: } U=\frac{0.38 g^{50 / 61} R^{89 / 61} \rho_{\ell}^{39 / 61}}{\mu^{39 / 61}} \text { for } R>R_{b}
\end{aligned}
$$

また， $R_{b}$ は気泡表面の污れにより気泡が流体球から固体 球となるときの気泡径の境界值であり水質に依存する. 気泡内部気体の分圧とモル数の関係を式(6)に示す.

$$
p_{j}=C_{j}\left(R_{I} / R\right)^{3 \kappa} M_{j}
$$

指数 は等温変化で 1 , 断熱変化では $7 / 5$ となる. $C_{j}$ は温 度に依存する定数である.

最後に，気泡半径はRayleigh-Plessetの方程式 ${ }^{-6)}$

$$
\begin{aligned}
\rho_{\ell}\left(R \ddot{R}+\frac{3}{2} \dot{R}^{2}\right)+\frac{2 \sigma}{R}+\frac{4 \mu \dot{R}}{R}-(p-P)=0 \\
p=p_{N}+p_{O}
\end{aligned}
$$

と式(6) を連立することにより計算される.ここで $\rho_{\ell}$ は 液体密度, $\sigma$ は表面張力係数, $\mu$ は液体の粘性係数, $P$ は気泡位置における液体の圧力である.

\section{（2）気体の溶解に関する考察（1清澄水などの場合）}

図-14に式(2)（3）から算定したSherwood数のReynolds 数依存性を示す. 低Reynolds数域ではSherwood数は2程 度であり, Reynolds数の増加に伴ってSherwood数が増加 することを示している. 気泡径が大きくなると静水中に 
おける浮上速度が増大しReynolds数は大きくなり, さら に気体溶解速度は $S_{j} R$ に比例するため, 結果的に大きな 気泡の気体溶解速度は大きいことが分かる。

図-15に式(4) (5) から算定した気泡半径と浮上速度の 関係を示寸。この図からマイクロバブルはミリバブルの 1/1000倍程度の浮上速度であり, 浮上中の気体の溶解時 間も長くなるため有利であることが分かる.

したがって，溶存酸素を効率良く上昇させるためには， 与えられた水深で浮上中にほぼ溶解する最大の気泡径を 持つ気泡を生成させることが必要となる，また，気泡の 浮上のみでなく, 水流を起こし, 流体および気泡の拡散 を促進させることも有効と考えられる.

\section{（3）曝気試験のシミュレーション（2)污れた水の場合）}

2 章で実施した曝気試験（CASE-C1，C2）のシミュ レーションを実施した。試験条件に合わせ， $10 \mathrm{~m}^{3}$ 水槽

(L3. $3 \mathrm{~m} \times$ B1. $7 \mathrm{~m} \times \mathrm{H} 1.8 \mathrm{~m})$ を対象に，水深 $1.6 \mathrm{~m}$ にお いて，適当な気泡径を持つ空気気泡を連続的に与えた場 合のD0の変化を計算した．ここで，初期のD0および窒素 の濃度は67.9\%，100\%とした。

計算では，式(1) (6) (7)を用い，時間発展させながら 溶存気体濃度の時間変化を求めた。 まず，式(6) (7) から, ある時間の各気体分圧および気泡半径を計算し，それら を式(1) (ヘンリーの法則) に代入し, 気泡内の各気体 の溶出速度を求める. 最後に増加した液体中の気体モル 数からその時間の気体分圧，溶存気体濃度（\%) を求め る. 上記の手法に従い，CASE-C2を想定し，半径60, 100 $\mu \mathrm{m}$ の気泡を $1 \mathrm{~L} / \mathrm{min}$ 発生させた結果（図-16），CASE-C1 を想定し，半径 $100 ， 500 \mu \mathrm{m}$ の気泡を $15 \mathrm{~L} / \mathrm{min}$ 発生させた 結果（図-17）を示す．図中黒丸は試験值である．図-16 および図-17より MB発生装置の気泡（CASE-C2）は半径60 $\sim 100 \mu \mathrm{m}$ 程度, エアストーンの気泡（CASE-C1）は半径 $500 \mu \mathrm{m}$ 程度であったと考えられる。 また，図-17より， MB発生装置により半径 $100 \mu \mathrm{m} の$ 気泡を $15 \mathrm{~L} / \mathrm{min}$ 供給した 場合は，エアストーン（半径500 $\mu \mathrm{m} の$ 気泡供給）に比べ 10倍の速さでD0が飽和濃度に達することが予想される.

\section{5. まとめ}

曝気による水域浄化では，水域の特性に応じた気泡の 添加が有効と考え，水質および曝気手法を変えた水槽試 験を行った. その結果, D0の増加速度は, 供給側では気 泡径および気体の種類, 受給側では水中の浮遊物質およ び溶解した不純物質により大きく影響を受けた。気体の 溶解の理論式および気体の溶解に影響寸る因子を整理す ることで，D0の効率的な増加には，与えられた水深で浮 上中にほぼ溶解する気泡径を持つ気泡の生成が有効であ ることが証明された. また, この理論式を用いることで,

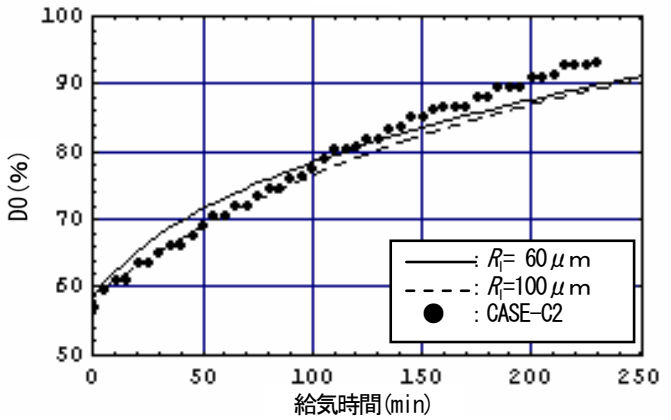

図-16 D0の増加 (CASE-C2, 空気量 : $1 \mathrm{~L} / \mathrm{min}$ )

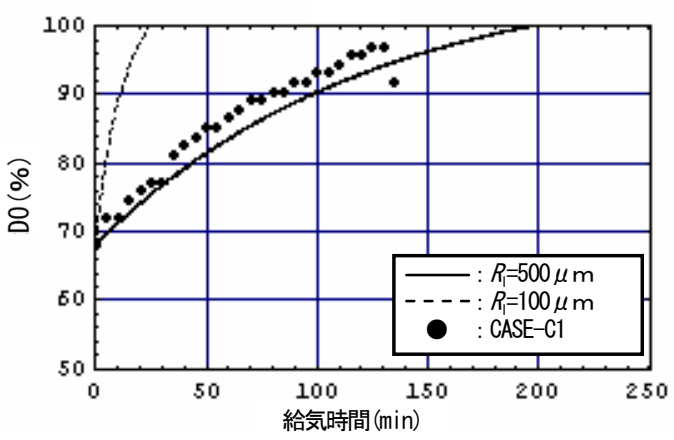

図-17 D0の増加（CASE-C1，空気量 : 15L/min）

試験で得られたD0の上昇が再現できることが確認された. 今回の結果は，曝気による水質浄化に活用できるものと 考える. しかし，限られた水質での検証であることから， 更に対象水質を増やし, 水質の影響を加味した曝気効果 を検証していく所存である.

謝辞 : 本論文は (学) 筑波大学, 佐藤工業(株) と若築建 設(株)の共同研究成果の一部の紹介であり，本論文をま とめるにあたって協力いただいた方々に謝意を表します。

\section{参考文献}

1）道奥康治, 神田徹, 大成博文, 森口昌仁, 松尾昌和, 白澤静 敏，松尾克美：マイクロバブルによる富栄養貯水池の水質改 善工と浄化効率, 水工学論文集, 第45巻, pp. 1201-1206, 2001.

2）大成博文，前田邦男，松尾克美，山原康嗣，渡辺勝利，石川 並木 : マイクロバブル技術によるカキ養殖効果, 水工学論文 集, 第46巻, pp. 1163-1168, 2002.

3) 辻村太郎, 京藤敏達 : 風波によるマイクロバブルの分散・拡 散とマイクロバブル浄化法の効果に関する研究，海岸工学論 文集，第52巻，pp. 1121-1125， 2005.

4) D. F. McGinnis and J. C. Little: Predicting diffused-bubble oxygen transfer rate using the discrete-bubble model, Water Research 36, pp.4627-4635, 2002.

5) R. Clift, J.R. Grace and M.E. Weber: Bubbles, Drops, and Particles, Academic Press, 1978.

6) M. S. Plesset and A. Prosperity: Bubble dynamics and cavitation, Ann. Rev. Fluid Mech., 9, pp.145-185, 1977. 